AGRICULTURE AND BIOLOGY JOURNAL OF NORTH AMERICA

ISSN Print: 2151-7517, ISSN Online: 2151-7525, doi:10.5251/abjna.2011.2.4.708.712

(C) 2011, ScienceHu $\beta$, http://www.scihub.org/ABJNA

\title{
Sub-acute toxicity study of a novel compound E-Octadec-7-en-5-ynoic acid from Capparis zeylanica Linn roots
}

\author{
Mahmuda Haque ${ }^{1}$ and Md. Ekramul Haque ${ }^{2}$ \\ ${ }^{1}$ Department of Pharmacy, Southeast University, Banani, Dhaka - 1213, Bangladesh \\ ${ }^{2}$ Department of Pharmacy, Rajshahi University, Rajshahi - 6205, Bangladesh
}

\begin{abstract}
E-Octadec-7-en-5-ynoic acid was isolated from the chloroform extract of the roots of Capparis zeylanica Linn and its sub-acute toxicity study was carried out on Long Evan's rats. The compound was administered at a dose of $300 \mu \mathrm{g} / \mathrm{rat} / \mathrm{day}$ for consecutive14 days. The studies included the gross general observation such as changes of body weight, hematological profiles [total count of Red Blood Cells (RBC) and White Blood Cells (WBC), differential count of WBC, platelet count and Hemoglobin $(\mathrm{Hb}) \%$ ], biochemical parameters of blood [ Serum Glutamate Oxaloacetate Transaminase (SGOT), Serum Glutamate Pyruvate Transaminase (SGPT), Serum Alkaline Phosphatase (SALP), urea, serum bilirubin and serum creatinine] and the histopathology of the heart,liver, kidney, and lung of both control and experimental groups of rats. The body weights of the rats were slightly increased. The changes in hematological and biochemical parameters were statistically not significant. No detectable abnormalities were found in the histopathology of the heart, liver, kidney, and lung in the experimental group of rats following the same dose when compared with the control group of rats. This preliminary study suggests that the isolated compound may be used safely for clinical trial.
\end{abstract}

Keywords: E-Octadec-7-en-5-ynoic acid, Capparis zeylanica, Sub-acute toxicity.

\section{INTRODUCTION}

Herbal medicines are popular remedies for diseases used by a vast majority of the world's population. The challenge of developing modern medicine for twenty first century needs more systemic research on the branch of medicine for welfare of the human being. Therefore, the worldwide increasing demand for medicine from natural sources has motivated search for new drugs with high potential activity (Rahman et al., 2001). In this intention attempts were taken to find out new drug from the plant Capparis zeylanica Linn. The plant locally known as Kalokera belongs to the family Capparidaceae is a rigid, wiry and much branched climbing shrub that is widely distributed throughout Bangladesh, India, the Philipines, Srilanka and Malaysia. In Northern India, the leaves are used as counter irritant, febrifuge and as a cataplasm in boils, swelling and piles (Kritikar, 1987). Analgesic and antipyretic effects (Ghule et al., 2007) and immunostimulant effects (Ghule et al., 2006) have been reported from the leaves of $C$. zeylanica Linn. A novel acetylenic fatty acid, E-Octadec-7-en-5-ynoic acid was isolated from the chloroform extract of C. zeylanica Linn roots (Haque et al., 2004) and its antibacterial and cytotoxic activities with crude have been reported (Haque et al., 2008).

Toxicology is the aspect of pharmacology that deals with the adverse effect of bioactive substance on living organisms (Alam et al., 2006) Depending on the duration of drug exposure to animals toxicological studies may be three type (acute, sub-acute and chronic toxicological studies) (Klaassen et al., 1996 ; Katzung,1994). In acute toxicity studies, single dose of drug is given in large quantity to determine immediate toxic effect. Acute toxicity studies are commonly used to determine $L_{50}$ of drug or chemicals. In sub- acute toxicity studies repeated doses of drug are given in sub-lethal quantity for a period of 14 to 21 days. Sub-acute toxicity studies are used to determine effect of drug on biochemical and hematological parameters of blood as well as to determine histopathological changes. In chronic toxicity studies, drug is given in different doses for a period of 90 days to over a year to determine carcinogenic and mutagenic potential of drug. In order to assess the safety and efficacy level of a new drug, toxicological studies are very essential experiments in animals like mice, rat, guinea pigs, dog, rabbit, monkey etc under various conditions of 
drug. No drug is used clinically without its clinical trial as well as toxicity studies. Toxicological data help to make decision whether a new drug is adopted for clinical use or not. This led to the present investigation on the sub-acute toxicity study of the compound E-Octadec-7-en-5-ynoic acid at a dose of $300 \mu \mathrm{g} / \mathrm{rat} /$ day on Long Evan's rat for consecutive14 days.

\section{MATERIALS AND METHODS}

Plant Material: The plant Capparis zeylanica Linn were collected during the months of December and January $(2000$ - 2001) from the adjoining areas of Rajshahi University campus and was identified by Prof. Naderuzzaman, Department of Botany, Rajshahi University. A voucher specimen (AEF NO. 28092) was deposited at Bangladesh National Herbarium, Dhaka. The roots were cleaned by washing with water, dried and pulverized into coarse powder using a grinding machine.

Extraction and Isolation of the Compound: The powder materials were extracted by cold percolation method with rectified spirit and subjected to solventsolvent partitioning with pet. ether, chloroform and methanol. The chloroform fraction was subjected to column chromatography followed by preparative thin layer chromatography to obtain a pure compound whose structure was established as E-Octadec-7-en5 -ynoic acid by extensive spectroscopic analysis (Haque et al., 2004).

Collection of Experimental Rats:The experiment was carried out on 8 Long Evan's male rats of about 6 months old. They were collected from the Animal Branch of International Center for Diarrhoeal Disease Research, Bangladesh (ICDDRB, B).

\section{MAINTENANCE OF RATS:}

The rats were kept in properly numbered iron cages individually in a hygienic animal house under temperature and light controlled condition (Khanna et al., 1989). They were fed a balance diet (Hawks et al., 1954). The animals were maintained in this condition for 15 days prior to administration of compound to adjust with food and environment and continued until completion of the experiment.

Grouping of Rats: Rats (8) were weighed individually and divided into two groups; group A (average body weight $103.75 \mathrm{~g}$ ) and group B (average body weight $105.13 \mathrm{~g}$ ), each comprising of 4 rats. Group A were used for control, while those of group B were used for experiment.
Administration of the Sample: The compound $E$ Octadec-7-en-5-ynoic acid was dissolved in distilled water with the help of tween -20 as a co-solvent in such a way that each $0.3 \mathrm{ml}$ of final solution contained $300 \mu \mathrm{g}$ of the compound. The rats in group $A$ and $B$ were injected intraperitoneally with vehicle $(300 \mu \mathrm{l}$ isotonic solution) and the compound respectively at a dose of $300 \mu \mathrm{g} / \mathrm{rat} /$ day for 14 consecutive days.

Gross General Observation: During the whole experimental period the rats were observed daily to note the following features: Behavior, CNS excitation and depression, reflexes, food intake, salivation, diarrhoea and muscular weakness. The body weight of each rat of groups A and B were measured before administration of drug and after completion of the treatment, prior to sacrificing the rats.

Investigation of Hematological Profiles: The hematological parameters like Total Count (TC) of RBC and WBC, Differential Count (DC) of WBC, platelet count and hemoglobin percentage were performed just before drug intake and after completion of treatment. For TC, DC and platelet count blood was drawn from the tail veins of the experimental and the control rats at $15^{\text {th }}$ day after completion of the treatment and blood smears were made on glass slides followed by staining with Leisman reagent (Ghai et al., 2004). Blood was also drawn from each rat with the help of capillary tube for estimating the hemoglobin percentage by Van Kampen- Ziftra's method (Ghai et al., 2004).

Investigation of Biochemical Parameters: For the determination of SGOT (Serum Glutamate Oxaloacetate Transaminase), SGPT (Serum Glutamate Pyruvate Transaminase), SALP (Serum Alkaline Phosphatase), urea, serum bilirubin and serum creatinine blood samples were collected separately from each of the control and experimental rat from their throat vein while they were sacrificed after 14 days of drug administration by using procedure and reagents as described in Englehringer Mannheim GmbH Diagnostica (Reitman et al., 1957; Fawcett et al., 1960).

Histopathological Investigation:Histopathological investigation was carried out at $15^{\text {th }}$ day after completing treatment and collection of blood. Both experimental and control groups rats were sacrificed and liver, kidney, heart and lung were isolated for investigation. The tissues were separately sliced in piece, fixed in $10 \%$ formalin for 3 days, processed, stained, mounted on glass slides and observed under 
high power microscope at the Department of Pathology, Rajshahi Medical College, Bangladesh.

\section{RESULTS AND DISCUSSION}

The structure of the compound whose toxicological studies were performed on rats in order to assess the safety of the compound is shown below:

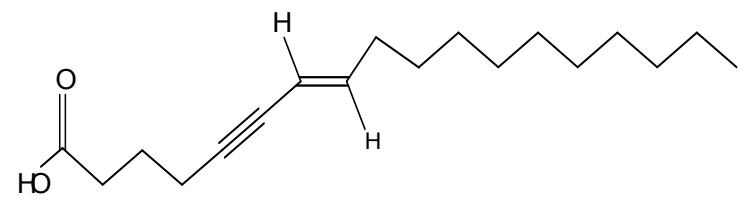

Table 1 showed that the rats of group A and B being treated with vehicle and the compound E-Octadec-7en-5-ynoic acid respectively exhibited no signs of tremor, convulsions and reflex abnormalities. The body weights of all the rats in each group were increased after treatment. Moreover, no muscular numbness of the hind and fore legs, salivation or diarrhea was observed. So, from the results, it is decided that the drug has no effect on normal growth.

E-Octadec-7-en-5-ynoic acid

Table 1: Effect of the compound on body weight of rats

\begin{tabular}{|c|c|c|c|c|c|c|c|}
\hline Group & $\begin{array}{l}\text { Dose(i.p.) } \\
\mu \mathrm{g} / \mathrm{rat} / \text { day }\end{array}$ & $\begin{array}{l}\text { Body weight(gm) before } \\
\text { drug administration } n=4 \text {, } \\
M_{1} \pm S D_{1}\end{array}$ & $\begin{array}{l}\text { Body weight(gm) after } \\
\text { drug administration } \\
n=4, M_{1} \pm S D_{1}\end{array}$ & $\begin{array}{l}\% \text { of } \\
\text { change }\end{array}$ & $t_{c}$ & $t_{s}$ & Remarks \\
\hline$A$ & $\begin{array}{l}300 \mu l \\
\text { vehicle }\end{array}$ & $\begin{array}{l}103.75 \pm 3.96 \\
(98,103,105 \& 109)\end{array}$ & $\begin{array}{l}109.75 \pm 3.56 \\
(105,109,110 \& 115)\end{array}$ & +5.78 & +2.26 & 2.447 & NS \\
\hline$B$ & $\begin{array}{l}300 \mu l \\
\text { compound }\end{array}$ & $\begin{array}{l}105.13 \pm 4.42 \\
(107,103.5,111 \& 99)\end{array}$ & $\begin{array}{l}110.35 \pm 4.4339 \\
(113,107,116 \& 106)\end{array}$ & +4.96 & +1.66 & 2.447 & NS \\
\hline
\end{tabular}

$t_{c}$ indicates calculated value; $t_{s}$ indicates $t$ value at $5 \%$ level of significance; $M_{1}$ and $M_{2}$ sample mean value; $\mathrm{SD}_{1}$ and $\mathrm{SD}_{2}$, standard deviation; n, number of rats; NS, not significant; +, increase.

Table 2: Hematological profiles of group A (rat treated with vehicle)

\begin{tabular}{|c|c|c|c|c|}
\hline \multirow{2}{*}{\multicolumn{2}{|c|}{ Hematological parameters }} & \multicolumn{3}{|c|}{ Normal rat treated with vehicle } \\
\hline & & $1^{\text {st }}$ day $M_{1} \pm S D_{1}$ & $7^{\text {th }}$ day $M_{2} \pm S D_{2}$ & $14^{\text {th }}$ day $\mathrm{M}_{3} \pm \mathrm{SD}_{3}$ \\
\hline \multirow{2}{*}{\multicolumn{2}{|c|}{ Total RBC count (million/cc) }} & $4.7,4.8,4.8,4.9$ & $5.1,5.3,5.2,5.4$ & $5.0,5.1,5.0,5.2$ \\
\hline & & $4.8 \pm 0.07$ & $5.25 \pm 0.11$ & $5.075 \pm 0.083$ \\
\hline \multirow{2}{*}{\multicolumn{2}{|c|}{ Total WBC count (thousand/cc) }} & $7.1,7.2,7.2,7.4$ & $7.0,7.1,7.3,7.2$ & $7.2,7.3,7.3,7.5$ \\
\hline & & $7.23 \pm 0.109$ & $7.12 \pm 0.112$ & $7.32 \pm 0.109$ \\
\hline \multirow{6}{*}{$\begin{array}{l}\text { Differential } \\
\text { count of WBC } \\
\text { in } \%\end{array}$} & Neutrophil & $41,44,45,40$ & $44,43,47,43$ & $44,42,45,40$ \\
\hline & & $42.5 \pm 2.06$ & $44.25 \pm 1.64$ & $42.625 \pm 2.0$ \\
\hline & Lymphocyte & $50,49,50,55$ & $52,51,50,52$ & $52,52,50,55$ \\
\hline & & $51 \pm 2.35$ & $51.25 \pm 0.83$ & $52.25 \pm 1.79$ \\
\hline & Monocyte & $7,6,4,35 \pm 1.58$ & $3,5,2,33.25 \pm 1.29$ & $2,4,4,33.25 \pm 0.83$ \\
\hline & Eosinophil & $2,1,1,21.5 \pm 0.5$ & $1,1,1,21.25 \pm 0.43$ & $2,2,1,21.75 \pm 0.43$ \\
\hline \multirow{3}{*}{\multicolumn{2}{|c|}{ Platelet count (no/cc) }} & 355000,340000 & 340000,345000 & 355000,350000 \\
\hline & & $\begin{array}{l}340000,350000 \\
346250 \pm 6495.19\end{array}$ & $\begin{array}{l}350000,345000 \\
345000 \pm 3535.53\end{array}$ & 345000,340000 \\
\hline & & & & $347500 \pm 5590.17$ \\
\hline \multirow{2}{*}{\multicolumn{2}{|c|}{ Hemoglobin (\%) }} & $13.2,13.8,13.8,13.8$ & $13.6,13.9,13.8,13.8$ & $12.8,13.7,13.3,13.3$ \\
\hline & & $13.65 \pm 0.25$ & $13.775 \pm 0.109$ & $13.32 \pm 2.21$ \\
\hline
\end{tabular}


Table 3: Hematological profiles of group B (rat treated with compound)

\begin{tabular}{|c|c|c|c|c|}
\hline \multirow{2}{*}{\multicolumn{2}{|c|}{ Hematological parameters }} & \multicolumn{3}{|c|}{ Normal rat treated with E-Octadec-7-en-5-ynoic acid } \\
\hline & & $1^{\text {st }}$ day $M_{1} \pm S D_{1}$ & $7^{\text {th }}$ day $M_{2} \pm S D_{2}$ & $14^{\text {th }}$ day $\mathrm{M}_{3} \pm \mathrm{SD}_{3}$ \\
\hline \multicolumn{2}{|c|}{ Total RBC count (million/cc) } & $\begin{array}{l}4.6,4.0,4.9,4.0 \\
4.38 \pm 0.39\end{array}$ & $\begin{array}{l}4.8,4.8,5.3,4.2 \\
4.78 \pm 0.39\end{array}$ & $\begin{array}{l}4.5,4.7,5.4,4.2 \\
4.7 \pm 0.442\end{array}$ \\
\hline \multicolumn{2}{|c|}{ Total WBC count (thousand/cc) } & $\begin{array}{l}7.5,7.6,7.6,7.4 \\
7.45 \pm 0.112\end{array}$ & $\begin{array}{l}7.7,7.9,7.5,7.6 \\
7.55 \pm 0.193\end{array}$ & $\begin{array}{l}7.8,7.9,7.6,7.5 \\
7.7 \pm 0.158\end{array}$ \\
\hline \multirow{4}{*}{$\begin{array}{l}\text { Differential } \\
\text { count of WBC } \\
\text { in } \%\end{array}$} & Neutrophil & $\begin{array}{l}39,44,41,40 \\
41.0 \pm 1.87\end{array}$ & $\begin{array}{l}43,47,43,42 \\
43.75 \pm 1.93\end{array}$ & $\begin{array}{l}41,45,40,43 \\
42.25 \pm 1.98\end{array}$ \\
\hline & Lymphocyte & $\begin{array}{l}55,50,51,48 \\
51 \pm 2.55\end{array}$ & $\begin{array}{l}53,48,50,51 \\
50.5 \pm 1.8\end{array}$ & $\begin{array}{l}51,48,52,53 \\
51.0 \pm 1.87\end{array}$ \\
\hline & Monocyte & $4,6,5,3 \quad 4.5 \pm 1.07$ & $\begin{array}{ll}4,4,2,3 & 3.25 \pm 0.82\end{array}$ & $3,4,2,2 \quad 3.25 \pm 0.82$ \\
\hline & Eosinophil & $2,3,2,1 \quad 2 \pm 0.7$ & $1,1,3,2 \quad 1.75 \pm 0.38$ & $2,2,1,2 \quad 1.75 \pm 0.43$ \\
\hline \multicolumn{2}{|c|}{ Platelet count (no/cc) } & $\begin{array}{l}345000,340000 \\
350000,350000 \\
346250 \pm 4145.78\end{array}$ & $\begin{array}{l}345000,345000 \\
350000,345000 \\
345000 \pm 2165.06\end{array}$ & $\begin{array}{l}350000,345000 \\
355000,350000 \\
350000 \pm 3535.5\end{array}$ \\
\hline \multicolumn{2}{|c|}{ Hemoglobin (\%) } & $\begin{array}{l}13.3,13.7,13.6,13.3 \\
13.475 \pm 0.179\end{array}$ & $\begin{array}{l}13.5,13.8,13.7,13.6 \\
13.65 \pm 0.11\end{array}$ & $\begin{array}{l}13 \cdot 0,13 \cdot 5,13 \cdot 2,13 \cdot 3 \\
13 \cdot 32 \pm 0.18\end{array}$ \\
\hline
\end{tabular}

Table 4: Effect of E-Octadec-7-en-5-ynoic acid on biochemical parameters of rats' blood after intraperitomeal administration of $300 \mu \mathrm{g} / \mathrm{rat} / \mathrm{day}$ for 14 consecutive days.

\begin{tabular}{|c|c|c|c|c|c|c|}
\hline $\begin{array}{l}\text { Biochemical } \\
\text { parameters }\end{array}$ & $\begin{array}{lll}\text { Group } & A, & n=4 \\
M_{1} \pm S D_{1} & & \end{array}$ & $\begin{array}{ll}\text { Group } & B, \quad n=4 \\
M_{2} \pm S D_{2} & \end{array}$ & $\begin{array}{l}\% \text { of } \\
\text { change }\end{array}$ & $t_{c}$ & $t_{s}$ & Remarks \\
\hline SGPT (IU/L) & $\begin{array}{l}8,10,8,9 \\
8.75 \pm 0.957\end{array}$ & $\begin{array}{l}11,9,10,9 \\
9.75 \pm 0.957\end{array}$ & -11.428 & 0.975 & 2.447 & NS \\
\hline SGOT (IU/L) & $8,9,9,88.5 \pm 0.5$ & $\begin{array}{l}10,7,8,10 \\
8.75 \pm 1.29\end{array}$ & +2.941 & 0.361 & 2.447 & NS \\
\hline SALP (IU/L) & $\begin{array}{l}45,48,44,40 \\
44.25 \pm 2.86\end{array}$ & $\begin{array}{l}46,42,47,45 \\
45 \pm 1.87\end{array}$ & +1.695 & 0.992 & 2.447 & NS \\
\hline Urea (mg/dl) & $\begin{array}{l}19,18,17,19 \\
18.25 \pm 0.83\end{array}$ & $\begin{array}{l}18,20,22,16 \\
19 \pm 2.23\end{array}$ & +4.109 & 0.63 & 2.447 & NS \\
\hline $\begin{array}{l}\text { Serum bilirubin (m } \\
\mathrm{mol} / \mathrm{L})\end{array}$ & $\begin{array}{l}0.26,0.28,0.29 \\
0.290 .28 \pm 0.014\end{array}$ & $\begin{array}{l}0.29,0.35,0.27 \\
0.290 .3 \pm 0.03\end{array}$ & +7.14 & 0.0092 & 2.447 & NS \\
\hline $\begin{array}{l}\text { Serum creatinine } \\
\text { (mg/dl) }\end{array}$ & $\begin{array}{l}0.85,0.8,1,0.75 \\
0.85 \pm 0.09\end{array}$ & $\begin{array}{l}1,0.85,0.85,0.9 \\
0.9 \pm 0.06\end{array}$ & +5.88 & 0.929 & 2447 & NS \\
\hline
\end{tabular}

NS = not significant

Table 2 and 3 showed hematological profiles that were studied on experimental rats in compared to control rats and 14 days of treatment. Each time the value of the parameters in each rat was changed slightly. However, the parameters remained within normal range.

Table 4 showed biochemical parameters on control group and treatment group of rats. The parameters remained within the normal range. This indicates the compound E-Octadec-7-en-5-ynoic acid has no adverse effect on liver and kidney function.

After 14 day of drug treatment, the rats of both control and experimental groups were sacrificed and the liver, kidney, lung and heart were isolated and examined under microscope. No abnormality was detected in the organs of both control experimental 
rats, indicating that the compound E-Octadec-7-en-5ynoic acid has no significant adverse effect on cellular structures (Table 5).

Table 5: Effect of compound (E-Octadec-7-en-5-ynoic acid) on histopatholpgy of rat's kidney, heart, liver and lung tissue after intraperitomeal administration of $300 \mu \mathrm{g} / \mathrm{rat} / \mathrm{day}$ for 14 consecutive days.

\begin{tabular}{|c|c|c|c|c|c|}
\hline \multirow{2}{*}{ Group } & \multirow{2}{*}{ 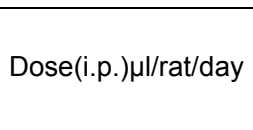 } & \multicolumn{4}{|c|}{$\begin{array}{l}\text { Observation of histopathological } \\
\text { change }\end{array}$} \\
\hline & & Heart & Liver & Kidney & Lung \\
\hline A & $300 \mu \mathrm{l}$ (Vehicle) & NAD & NAD & NAD & NAD \\
\hline$B$ & $300 \mu \mathrm{l}($ Compound) & NAD & NAD & NAD & NAD \\
\hline
\end{tabular}

NAD = No abnormality detected

The results of present study demonstrate that the compound E-Octadec-7-en-5-ynoic acid possess no adverse effect on Long Evan's rats at a dose of 300 $\mu \mathrm{g} / \mathrm{rat} / \mathrm{day}$. Thus the findings of this investigation would give valuable support to make clinical trial of the isolated compound.

\section{ACKNOWLEDGEMENT}

The authors are pleased to acknowledge Dr. Anwar Habib, Assistant Professor, Department of Pharmacology, Rajshahi Medical College, Rajshahi, Bangladesh for his cooperation and help in studying subacute toxicity study of the compound E-Octadec7-en-5-ynoic acid.

\section{REFERENCES}

Alam, A.H.M.K., Islam, R., Salam, K.A., Manir, M. M., Baki, M.A., Hossain M.A. and G. Sadik (2006). Toxicological studies of $\mathrm{N}$ - trans- ferloyl- 4methyldopamine isolated from Achranthes ferruginea. Pakistan Journal of Biological Sciences, 9: 1052-1055.

Fawcett, J.K. and Scott J.F. (1960). A new semimicro method for determination of urea. J. Cli.Pathol. 13: 156-159.

Ghai, C.L. (2004). A Text Book of Practical Physiology. $6^{\text {th }}$ End. Jaypee Brothers Medical Publishers, New Delhi, pp 130-175.

http://www.nbcindia.com/Description.asp?6v6yr vq=GHIM G\&Buy+Book+Online=A+Textbook+of+Practical+Physi ology\&by=Ghai

Ghule,B.V., Murugananthan, G., Nakhat, P.D. and Yeole, P.G. (2006). Immunostimulant effects of Capparis zeylanica Linn. Leaves. Fitoteripia, 108(2): 311-315.

doi:10.1016/j.jep.2006.03.041
Ghule,B.V., Murugananthan, G. and Yeole, P.G. (2007). Analgesic and antipyretic effects of Capparis zeylanica leaves. Fitoteripia, 78(5): 365-369.

\section{doi:10.1016/j.fitote.2007.02.003}

Haque, M. E., Haque, M., M.M. Rahman, M.M., Rahman, M.M., Khondkar, P., Wahed, M. I.I., Mossadik, M.A., Gray, A.I. and Sarker, S.D. (2004). E-octadec-7-en-5ynoic acid from the roots of Capparis zeylanica. Fitoteripia, 75(2): 130-133.

\section{doi:10.1016/j.fitote.2003.11.004}

Haque, M., Haque, M. E., Rahman, M.M., Khondkar, P. and. Rahman, M. M. (2008). Antibacterial and cytotoxic activities of Capparis zeylanica Linn roots. Ars. Pharmaceutica, 49: 31- 37.

Hawks, P.B., Oser, L. and Summerson, W.H. (1554). Practical Physiological Chemistry. $13^{\text {th }}$ ed., McGraw Hill BooK Company, US, pp 394-394.

Katzung, B.G. (1994). Basic and Clinical Pharmacology. $6^{\text {th }}$ ed., Prentice- Hall International In., California, pp 879881.

Khanna, N., Ray, A., Alkondon, M. and Sen, P. (1989). Effect of $\beta$-adrenoceptor antagonists and some related drugs on maximal electroshock seizures in mice. Indian Journal of Experimental Biology, 27: 128130.

Klaassen, C.D. (1996). Principle of Toxicology and Treatment of Poisoning. In: Goodman and Gilman's The Pharmacological Basis of Therapeutics, eds., Hardman, J.G., L.E. Limbird, P.B. Molinoff, R. W. Ruddon and A.G. Gilman. $9^{\text {th }}$ ed., McGraw- Hill Companies, United States, America, pp 63-74.

Kritikar, K. R. (1987). Indian Medicinal Plants. Oriental Enterprises, Dehradun, India, pp 200-2001.

Rahman, M.M., Wahed, M.I.I., Biswas, M.H., Sadik, G. M. and. Haque, M.E (2001). In vitro antibacterial activity of the compounds of Trapa bispinosa Roxb. Science, 1: 214-216.

http://scholar.google.com/scholar?hl=en\&lr=\&q=+2001\%2B In+vitro+antibacterial+activity+of+the+compounds+of+ Trapa+bispinosa+Roxb.+Science $\% 2 \mathrm{C}+1 \% 3 \mathrm{~A}+214-$ 216\&btnG=Search

Reitman, S. and Frankel, F.D. (1957). A calorimetric method for the determination of serum glutamateoxalate and pyruvate transaminases. Am. J. Clin. Pathol., 28: 56-63. 